\title{
Change Order Management Factors in Building Projects in Northern Nigeria
}

\author{
Kolawole A. Richard ${ }^{1}$, Kamau K. Peter ${ }^{1} \&$ Munala Gerryshom ${ }^{2}$ \\ ${ }^{1}$ Department of Environmental Planning \& Mgt, Kenyatta University, Nairobi, Kenya \\ ${ }^{2}$ Centre for Urban Studies, Jomo Kenyatta University of Agriculture and Technology, Nairobi, Kenya \\ Corresponding: Kolawole A. Richard, School of Environmental Studies, Kenyatta University, P.O.Box 43844 \\ -00100, Nairobi, Kenya. Tel: 25-478-815-8708. E-mail: rakolawole2013@gmail.com
}

Received: October 21, 2015 Accepted: November 9, 2015 Online Published: December 21, 2015

doi:10.5539/ass.v12n1p223 URL: http://dx.doi.org/10.5539/ass.v12n1p223

\begin{abstract}
A change is an amendment or addition with respect to the original plans, specification or other contract documents and vital factor in construction project management. A change order is an instruction from an employer approving a change. Construction projects in Nigeria have suffered deleteriously as a consequence of extensive change orders, which has manifested in cost and time overruns, disputes, arbitration, litigation and even the abandonment of projects and this negatively impacts on the efficiency of the Nigerian construction industry.This paper explore the extent change order management strategies correlate with overall building project in Nigeria. Thirty strategies for managing change order were identified through intensive literature search Twenty -one factors peculiar to the Nigerian construction industry were used to develop a questionnaire. A total of 323 questionnaires were administered through stratified random sampling to respondents in the cities of Abuja, Kano and Bauchi. The study targeted construction Consultants namely Architects, Quantity Surveyors Building Engineers, Service Engineer (Electrical \& Mechanical), Contractor and Building owners in three sub-study cities. The study recorded an overall response rate of $80.8 \%$. Using SPSS version 22, the questionnaire was subjected to reliability test. Statistical analysis was used using average index; spearman correlation coefficient; factor analysis and multiple regression were used to analysis data from survey questionnaire. The study reveal that change orders are better manage at the design stage and that clear and thorough project brief, better initial planning and thorough detailing of design are the three topmost management strategies. The study established that overall project success is impacted by change order management with a $\mathrm{R}^{2}$ of 0.252 , meaning that change order management at the design stage accounts for $25.2 \%$ of the variation in building project outcomes. The Spearman's (rho) also show strong agreement among respondents. The study concluded that proper adoption and use of project implementation phase principles by project sponsor, increased effort at the design stage of projects by project participant and allocation of adequate resources to project requirement will help minimize change orders in project delivery in Northern Nigeria
\end{abstract}

Keywords: change order, cross -validation, management, Nigeria, project success

\section{Introduction}

A change is an amendment or addition in respect to the original plans, specification or other contract credentials. A change order is an instruction from an employer approving a change (Park, 2002). Change is a significant and vital factor in construction project management (Ibbs, Wong, \& Kwak, 2001; Motowa, Anumba, Lee, \& Pena-Mora, 2007) and it is a matter of practical reality, because construction project complexity makes it almost impossible to deliver a building project without changes in its plans or the construction method itself. Changes in construction projects are regular and are likely to occur from varied sources, by a range of causes, at any phase of a project and may have wide-ranging impact (Motowa et al., 2007). Construction projects in Nigeria have suffered deleteriously as a consequence of extensive change orders, which has manifested in cost and time overruns, disputes, arbitration, litigation and even the abandonment of projects. This has negatively impacts on the efficiency of the Nigerian Construction Industry (NCI) (Ade-Ojo \& Babalola, 2013; Aibinu \& Jagboro, 2002). These amongst other factors have made the NCI unable to address the huge shortfall of basic amenities, essential public infrastructure, and population pressure on the urban centre's resulting in $60 \%$ of urban inhabitants lacking housing (Dahiru \& Mohammed, 2012). Oladapo (2007) and Sunday (2010) believes that change orders are 
responsible for cost overruns of between $25-78 \%$ and time overruns of between $27-68 \%$ of projects. As a result of the important role this industry plays in a nation's economy, it is very important to maintain successful delivery of construction project in Nigeria. Effective management of change orders to avoid failed projects could help in this regard. Although, many studies related to managing change orders have been conducted in other countries (Sun et al., 2006; Motowa et al., 2007) little or no research was found that illustrate to what extent change order management strategies contributes to building project outcome. This paper therefore explore extent to which change order management strategies correlate with overall building project success.

\subsection{Objective}

(i) To evaluate management strategies that can significantly curtail change order in building project; and

(ii) To establish the relationship between change order management strategies and building project success.

\section{Research Background}

Change order is unavoidable in construction projects because of the multifarious nature of building projects. Oloo, Munala and Githae (2014) asserted that change orders are common to all types of projects and therefore play a fundamental role in determining final project cost and time. According to Pourrostam and Ismail (2011) the reason for failure by contractor to complete projects within budgeted time are because of change orders. Erdogan, Anumba, Bouchlaghem and Nielsen (2005) pointed out that changes will never disappear, therefore the best alternative is to manage them to prevent negative consequences. Ibbs et al., (2001) on their part concluded "that the litmus test for successful management should not be whether project was free of change orders, but rather, if change orders were resolved in a timely manner to the benefit of all the parties and the project".

\subsection{Change Order Management Factors}

A change order is intricate information transfer that has to be dealt with carefully, otherwise dispute related to cost and time of work may occur between client and contractor. " Change order is complex because it involves all construction team, together with a huge amount of information that either has to be ask for, sent, checked, corrected, permitted, classified conveyed or submitted, among other things" (Charoenngam, Coquinco, \& Hadikusumo, 2003). Owing to this complexity, methods to manage change orders have been proposed in research studies (Ibbs, et.al., 2001;Mokhtar, Bedard, \& Fazio, 2000). Table 1 shows the tabulation of 30 management strategies identified in literature. Twenty - one strategies found to be peculiar to the Nigerian Construction Industry were regrouped under two categories: Design and Construction stage. These grouping helped in developing an all-embracing enumeration of management strategies for change orders. These strategies formed the basis for the questionnaire survey (Table 3).

Table 1. Management strategies for change orders

\begin{tabular}{lll}
\hline S/N & Management strategies & Identified Author(s) \\
\hline $\mathbf{1}$ & Review of contract documents & CII, (1994a) \\
$\mathbf{2}$ & Freeze design & CII, (1990a) \\
$\mathbf{4}$ & Value engineering at conceptual phase & Dell'Isola, (1982) \\
$\mathbf{5}$ & Involve professionals at initial stages of project & O'Brien, (1998); Arain et al., (2004) \\
$\mathbf{6}$ & Involve contractor at planning and scheduling process & Fisk, (1997) \\
$\mathbf{7}$ & detail the design & Arain et al., (2004) \\
$\mathbf{8}$ & Have a clear and thorough project brief & O'Brien, (1998) \\
$\mathbf{9}$ & Reduce contingency sum & O'Brien, (1998) \\
$\mathbf{1 0}$ & Clarify change order procedure & Arain \& Pheng, (2005) \\
$\mathbf{1 1}$ & Have written approvals & Mokhtar et al., (2000); Ibbs et al., (2001) \\
& & CII, (1990a); Hester et al., (1991); Cox, \\
$\mathbf{1 2}$ & Change order scope & (1997) \\
$\mathbf{1 3}$ & Change logic and justification & CII, (1994b); Ibbs et al., (2001) \\
$\mathbf{1 4}$ & Get a project manager from an independent firm to manage the project & Ibbs et al., (2001) \\
$\mathbf{1 5}$ & Restrict pre-qualification system for awarding projects & Chan \& Yeong, (1995); Fisk, (1997) \\
$\mathbf{1 6}$ & Involve owner in the construction phase & Ibbs et al., (2001) \\
\hline
\end{tabular}


17 Avoid use of open tendering

18 Use project scheduling/ management techniques

19 Comprehensively document change order

20 Promptly approval procedure

21 Negotiate change order

22 Value indirect effects

23 Ensure team effort by owner, consultant and contractor to control change orders

24 Utilize work breakdown structure

25 Ensure continuous coordination and direct communication

26 Control the potential for change orders arising from contractual clauses

27 Ensure comprehensive site investigation

28 Use collected and organized project data compiled by owner, consultant and contractor

29 Ensures knowledge base of previous similar projects

30 Comprehensively analyse and promptly decide using a computerized knowledge-based decision support system.
Chan \& Yeong, (1995)

Hester et al., (1991);Clough \& Sears, (1994); Mokhtar et al., (2000)

Cox, (1997); O'Brien, (1998); Fisk, (1997)

Fisk, (1997)

Clough \& Sears, (1994); Cushman \& Butler, (1994)

Ibbs et al., (2001); Fisk, (1997)

CII, (1994a); Assaf et al., (1995)

Hester et al., (1991); Mokhtar et al., (2000)

Assaf et al., (1995)

CII, (1990a); Cox, (1997)

Assaf et al., (1995); Fisk, (1997)

CII, (1994a); Fisk, (1997)

CII, (1994b); Miresco \& Pomerol, (1995);

Miresco \& Pomerol, 1995); Ibbs et al., (2001)

Source: (Arain \& Pheng, 2006)

\subsection{Project Success Criteria}

Project success has been measured in diverse ways over the past two and half decades. However, appraisal was determined mainly by meeting three decisive factors of time, cost and quality (Atkinson, 1999). However, many researchers have disagreed with these criteria as the only way to measure outcome, since project outcomes are more complex because their characteristics vary from project to project. According to Shenhar et al., (1997) cited in Al- tmeeny, Abdul-Rahman \& Haron (2010) although time, cost and quality are handy measures, they have been disapproved for not really being one homogenous measurement. These shortcomings of the conventional way of measuring success led to additional success measures proposed such as: satisfaction of interpersonal relation with project team members, client's satisfaction, fitness of purpose, profitability, and project goals (Frodell, 2008; Lim \& Mohammed, 1999; Pinto \& Pinto, 1991; Pocock, Hyun, Lim, \& Kim, 1996). This paper considered only cost and time as measures of project success because they are the objective measures mostly referred to in the Nigerian construction industry. Other measures were included as dummy variable to ascertain this measures. These factors form part of the questionnaire for the survey as shown in Table 2.

Table 2. Success criteria

\begin{tabular}{ll}
\hline S/N & Success Criteria \\
\hline 1 & Project completed within budget prescribed at project outset \\
2 & Safety and environment \\
3 & Project completed within time according to schedule determine at project outset \\
4 & Project outcome(product,system,service etc) met all technical specified requirement \\
5 & Environmental Impact Assessment (EIA) score \\
6 & Projects meets stakeholders satisfaction \\
7 & Satisfaction of interpersonal relations with project team member \\
8 & Comprehensive Contract documentation \\
9 & Profitability \\
10 & Projects outcome was used for it intended purpose. \\
11 & Projects adherence to quality based on baselines goals ,target and expectations \\
\hline
\end{tabular}

Source: Kylindri, Blanas, Henriksen \& Stoyan (2012) 


\section{Research Methodology}

An extensive literature review was done, a number of management strategies and building success indicators were extracted. Those factors found to be very relevant to Nigeria were used to form the basis of the questionnaire. A structured questionnaire of 32 factors organised in 5-point Likert scale was developed and employed to elicit information from respondents on: demographic profiles, management strategies and project success criteria. Each respondent was asked to rate each factor based on their professional judgement. The level of severity was then assesses and ranked according to their responses. The study targeted construction Consultants namely Architects, Quantity Surveyors Building Engineers, Service Engineer (Electrical \& Mechanical), Building contractor who are involved in construction and Owners(comprising government agency and individuals) in three sub - study cities in the Northern geo-political region of Nigeria A total of 323 questionnaires were evenly administered through stratified random sampling to respondents in the cities of Abuja, Kano and Bauchi. These cities have the highest concentration of construction activities in northern Nigeria (Ameh \& Odusami, 2010, Usman, Inuwa, Iro, \& Dantong, 2012) and are located in the three geo-political regions of Northern Nigeria respectively. The descriptive data of respondent indicate that Architects constitute (13\%), Quantity Surveyor (18.58\%), Building Engineer (15.79\%), Building Service Engineers (18.89) Building Contractor (17.76\%) and Building Owners (15.79\%). The respondent were experienced (with average of 10 years in the construction industry).The study recorded an overall response rate of $80.8 \%$. This rate is comparable to other studies in the Nigerian construction industry of 83\% (Ade-ojo \& Babalola 2012; Ubani, Nwachukwu \& Nwokonkwo, 2012). The reliability and consistency of the questionnaire construct was measured using Cronbach's alpha and it showed that items in change order management factor and project success factors is 0.78 and 0.83 respectively. According to Ogwueleka (2011), alpha greater that 0.7 implies the instrument is acceptable. According to the above results, it signifies high reliability and consistency of the instrument.

Analyses were aimed at establishing the importance of management strategies and their relationship with building project success. Four statistical tools were used. They are Average index; Spearman rank correlation (rho); Factor analysis and multiple regressions analysis of data from the survey questionnaires. Average Index (AI) was used to establish the relative importance of change management strategies. The formula used is:

$$
A I=\frac{\sum X 1+X 2+X 3=X 4+X 5}{N}
$$

For assessing the effectiveness of the management strategies, scale was modified as:

$X_{1}=$ Number of respondent for poor factor

$\mathrm{X}_{2}=$ Number of respondent for fair factor

$\mathrm{X}_{3}=$ Number of respondent for good factor

$\mathrm{X}_{4}=$ Number of respondent for very good factor

$\mathrm{X}_{5}=$ Number of respondent for excellent factor

$\mathrm{N}=$ Number of respondents

To determine whether there is degree of agreement among the three groups of respondents with respect to their ranking of the factors, Spearman's correlation coefficient was used. The spearman correlation coefficient says that the degree of agreement on a zero to one scale is:

$$
\rho=1-\frac{6 \sum d_{i}^{2}}{n\left(n^{2}-1\right)}
$$

In order to know whether there is disagreement or agreement between the three groups on ranking the factors, a test hypothesis was needed.

Null hypothesis: There is no agreement on strategies used in managing change orders in building projects.

Alternative hypothesis: There is agreement on strategies used in managing change orders in building projects.

Factor analysis in this paper was used to uncover patterns by exploring the dataset. It was conducted using a two stage process: factor extraction and factor rotation. Factor extraction is to determine the factors using Principal Component Analysis (PCA), whereas factor rotation is to make the factor more interpretable. Other tests were to determine the appropriateness of factor for analysis and extraction. Kaiser -Meyer - Olkin (KMO) measure sampling adequacy and Bartlett test of Sphericity was used to test the presence of correlation among the variables. Multiple regression was used to explore the relationship between the independent variables to the dependent variable. In this paper, the independent variable are change order management strategies at design and construction stages. The model dependent variable is building success. 


\subsection{Results}

\subsubsection{Ranking of Management Strategies and Success Factors}

The management strategies and success factors were analyzed and ranked according to respondents' responses based on arithmetic mean value and standard deviation. Table 3 shows the combined ranking of respondents in management strategies of change orders.

Table 3. Management strategies of change orders

\begin{tabular}{|c|c|c|c|c|}
\hline \multirow[t]{2}{*}{$\mathrm{S} / \mathrm{N}$} & \multirow[t]{2}{*}{ Management Factors } & \multicolumn{3}{|c|}{ Group } \\
\hline & & Mean & Std Dev & Rank \\
\hline & DESIGN STAGE (DS) & & & \\
\hline 1 & Clear and thorough project brief & 4.3758 & 0.7962 & 1 \\
\hline 2 & Better initial planning & 4.3489 & 0.7135 & 2 \\
\hline 3 & Thorough detailing of design & 4.2741 & 0.7903 & 3 \\
\hline 4 & Involvement of relevant professionals at initial stages of project & 4.1776 & 0.8457 & 4 \\
\hline 5 & Awarding the tender to the right contractor & 4.1739 & 0.9073 & 5 \\
\hline 6 & $\begin{array}{l}\text { Standardization of procedure for projects from the start of the project until } \\
\text { completion and close out }\end{array}$ & 4.1118 & 0.8240 & 6 \\
\hline 7 & Allocation of sufficient time for design development & 4.0311 & 0.8197 & 9 \\
\hline 8 & Comprehensive site investigation & 3.9656 & 0.8899 & 10 \\
\hline 9 & Application of Value Engineering at Conceptual phase & 3.7278 & 0.8778 & 14 \\
\hline 10 & Reducing contingency Sum & 3.0438 & 1.1217 & 18 \\
\hline \multirow[t]{2}{*}{11} & Award contract on fixed sum basis & 3.0155 & 1.1451 & 19 \\
\hline & CONSTRUCTION STAGE (CS) & & & \\
\hline 1 & Team effort by owner; consultant and contractor to control variation orders & 4.0870 & 0.8308 & 7 \\
\hline 2 & Comprehensive documentation of variations orders & 4.0373 & 0.8715 & 8 \\
\hline 3 & Continuous coordination and direct communication & 3.9377 & 0.9164 & 11 \\
\hline 4 & Prompt approval procedure & 3.8847 & 0.8417 & 12 \\
\hline 5 & Clarity of change order procedure & 3.8365 & 0.8283 & 13 \\
\hline 6 & Appointment of independent professional to manage the project & 3.6770 & 0.9144 & 15 \\
\hline 7 & Use of shared database (change management system) & 3.6273 & 0.9226 & 16 \\
\hline 8 & Utilize work breakdown structure(WBS) & 3.4748 & 1.0098 & 17 \\
\hline 9 & Avoiding the use of open tendering & 2.9841 & 1.1605 & 20 \\
\hline 10 & Avoiding the use of Nominated sub- contractors & 2.9283 & 1.0655 & 21 \\
\hline
\end{tabular}

Source: Field Survey (2014)

Table 3 shows the descriptive statistical analysis of the combined weighted means of the respondent, level of significant of management strategies during design stage ranges between 4.38 - 3.02. This shows all identified factors are significant to controlling change orders. This finding indicates that the design stage was considered as the most important time-line for executing the most effective controls for change orders because the first five management strategies appeared under the design phase. A possible explanation for this is that changes during design phase do not require any rework or pulling down because no site work is involved. This finding aligns with those of Arain and Pheng (2007) and Motowa (2005) that change orders are better controlled at the design level.

Table 4 also shows descriptive statistical analysis of respondents' views on success criteria. The outcome reveals that the two most ranked success criteria are: project completion within budget with mean value of (4.34) and project completion within time with mean value (4.23). This finding collaborate those of Atkinson (1999) and Chan (2000) that identified cost ,time and quality as key performance indicators of project success in their studies. 
Table 4. Ranks of success criteria

\begin{tabular}{llccc}
\hline \multirow{2}{*}{ S/N } & \multicolumn{1}{c}{ Success Criteria } & \multicolumn{3}{c}{ Group } \\
\cline { 3 - 5 } & & Mean & Std Dev & Rank \\
\hline 1 & Project completed within budget prescribed at project outset & 4.3437 & 0.7976 & 1 \\
3 & Project completed within time according to schedule determine at project outset & 4.2384 & 0.8240 & 2 \\
4 & Project outcome(product,system,service etc) met all technical specified requirement & 4.2243 & 0.7942 & 3 \\
11 & Projects adherence to quality based on baselines goals ,target and expectations & 4.1858 & 0.7779 & 4 \\
10 & Projects outcome was used for it intended purpose. & 4.0774 & 0.8057 & 5 \\
6 & Projects meets stakeholders satisfaction & 4.0093 & 0.8358 & 6 \\
2 & Safety and environment & 3.9410 & 0.9793 & 7 \\
8 & Comprehensive Contract documentation & 3.9164 & 0.9567 & 8 \\
7 & Satisfaction of interpersonal relations with project team member & 3.8947 & 0.8712 & 9 \\
9 & Profitability & 3.7391 & 0.9341 & 10 \\
5 & Environmental Impact Assessment (EIA) score & 3.6192 & 0.9327 & 11 \\
\hline
\end{tabular}

Source: Field Survey (2014)

\subsection{Level of Agreement among Respondents}

To determine whether there is degree of agreement among the three groups of respondents with respect to their views of the change order management factor, Spearman rank correlation coefficient was used.

Table 5. Spearman's rank correlation coefficient - management factor

\begin{tabular}{cccc}
\hline Respondents & Professional & Contractors & Owners \\
\hline Professional & 1 & 0.953 & 0.892 \\
Contractors & & 1 & 0.889 \\
Owners & & & 1 \\
\hline
\end{tabular}

Correlation is significant at the 0.1 level ( 2-tailed)

Table 5 indicated strong agreement amongst respondents in the ranking of the management strategies. This finding suggests the rejection of the null hypothesis Ho and alternative hypothesis accepted. Therefore, it can be concluded that there is a significant degree of agreement between the groups of respondent. Next the variables were assessed for their suitability of the factor analysis application. These variables were subdivided into two groups under design phase (11 variables) and construction phase (10 variables) Table 6 and 7 shows that KaiserMeyer- Oklin (KMO) value was 0.737 and 0.70 for design and construction item respectively, exceeding the recommended value of 0.5 (Field, 2009) an indication of factorability of the variables.

Table 6. KMO and Bartlett's test for design items

\begin{tabular}{lcc}
\hline \multicolumn{2}{c}{ Kaiser-Meyer-Olkin Measure of Sampling Adequacy. } & .737 \\
\hline \multirow{3}{*}{ Bartlett's Test of Sphericity } & Approx. Chi-Square & 608.257 \\
& df & 55 \\
& Sig. & .000 \\
\hline
\end{tabular}

Table 7. KMO and Bartlett's test for construction items

\begin{tabular}{lcc}
\hline \multicolumn{2}{c}{ Kaiser-Meyer-Olkin Measure of Sampling Adequacy. } & .700 \\
\hline \multirow{3}{*}{ Bartlett's Test of Sphericity } & Approx. Chi-Square & 465.309 \\
& $\mathrm{df}$ & 45 \\
& $\mathrm{Sig}$. & .000 \\
\hline
\end{tabular}


The Bartlett's test of sphericity $(55)=608.257, \mathrm{p}<0.001$ and Bartlett's test of sphericity $(45)=465.309, \mathrm{p}<0.001$ for design and construction item respectively. This KMO value verifies the sampling adequacy for the analysis and the Bartlett's test of sphericity. The results of these confirm that the sample data were suitable for factor analysis.

Factor analysis was then carried out to examine the relation between observed and latent variable (s). The eigenvalues criterion stated that each component explained at least one variable's worth of the variability and for that reason component with eigenvalues greater than 1 should be taken. This analysis yielded three components with eigenvalues bigger than 1 , accounting for $52.111 \%$ of the total variance in the 11 management strategies at the design phase and three components with eigenvalues bigger than 1, accounting for $52.313 \%$ of the total variance in the 10 management strategies at the construction phase. (Table 8 and 9).

Table 8. Total variance explained for design variables

\begin{tabular}{ccccccc}
\hline \multirow{2}{*}{ Component } & \multicolumn{3}{c}{ Initial Eigenvalues } & \multicolumn{3}{c}{ Extraction Sums of Squared Loadings } \\
\cline { 2 - 7 } & Total & \% of Variance & Cumulative \% & Total & \% of Variance & Cumulative \% \\
\hline 1 & 3.013 & 27.392 & 27.392 & 3.013 & 27.392 & 27.392 \\
2 & 1.630 & 14.820 & 42.212 & 1.630 & 14.820 & 42.212 \\
3 & 1.089 & 9.899 & 52.111 & 1.089 & 9.899 & 52.111 \\
4 & .970 & 8.822 & 60.933 & & & \\
5 & .868 & 7.892 & 68.825 & & & \\
6 & .762 & 6.925 & 75.749 & & & \\
7 & .675 & 6.140 & 81.890 & & & \\
8 & .567 & 5.156 & 87.046 & & & \\
9 & .508 & 4.619 & 91.664 & & & \\
10 & .500 & 4.549 & 96.214 & & & \\
11 & .417 & 3.786 & 100.000 & & & \\
\hline
\end{tabular}

Extraction Method: Principal Component Analysis.

Table 9. Total variance explained for construction variables

\begin{tabular}{ccccccc}
\hline \multirow{2}{*}{ Component } & \multicolumn{3}{c}{ Initial Eigenvalues } & \multicolumn{3}{c}{ Extraction Sums of Squared Loadings } \\
\cline { 2 - 7 } & Total & \% of Variance & Cumulative \% & Total & \% of Variance & Cumulative \% \\
\hline 1 & 2.642 & 26.419 & 26.419 & 2.642 & 26.419 & 26.419 \\
2 & 1.589 & 15.893 & 42.312 & 1.589 & 15.893 & 42.312 \\
3 & 1.000 & 10.001 & 52.313 & 1.000 & 10.001 & 52.313 \\
4 & .941 & 9.415 & 61.727 & & & \\
5 & .906 & 9.065 & 70.792 & & & \\
6 & .772 & 7.723 & 78.515 & & & \\
7 & .650 & 6.501 & 85.016 & & & \\
8 & .590 & 5.897 & 90.913 & & & \\
9 & .479 & 4.787 & 95.700 & & & \\
10 & .430 & 4.300 & 100.000 & & & \\
\hline
\end{tabular}

Extraction Method: Principal Component Analysis.

The three component solution explained a sum of the variance with component contributing 27.392\%; component 2 contributing $14.820 \%$ and component 3 contributing $9.899 \%$ for variable at design phase. While the three component solution explained a sum of the variance with component contributing $26.419 \%$; component 2 contributing $15.893 \%$ and component 3 contributing $10.001 \%$ for variable at construction phase However, an assessment of the Scree-plots (Figure 1 and Figure 2) showed the points of inflexion occurring on the third data point (factor); justifying retaining 2 components each. 


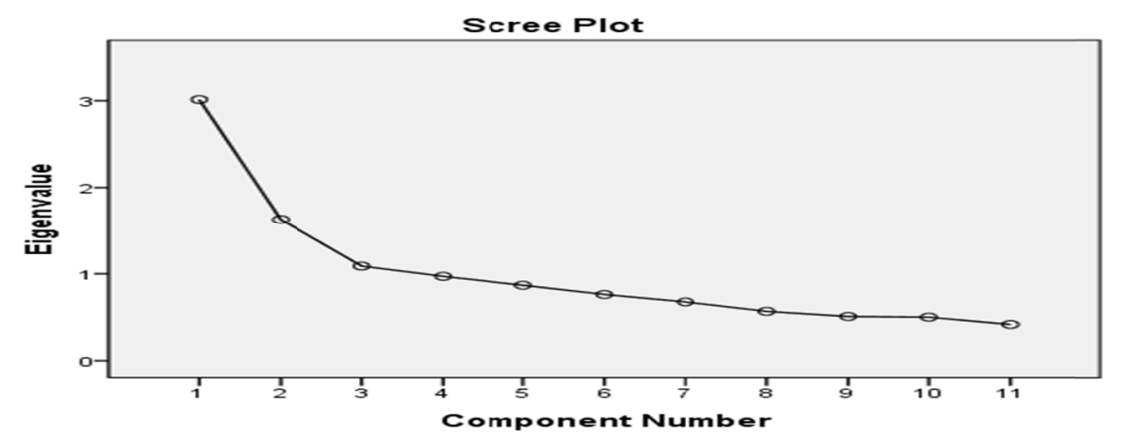

Figure 1. Scree plot for design variables

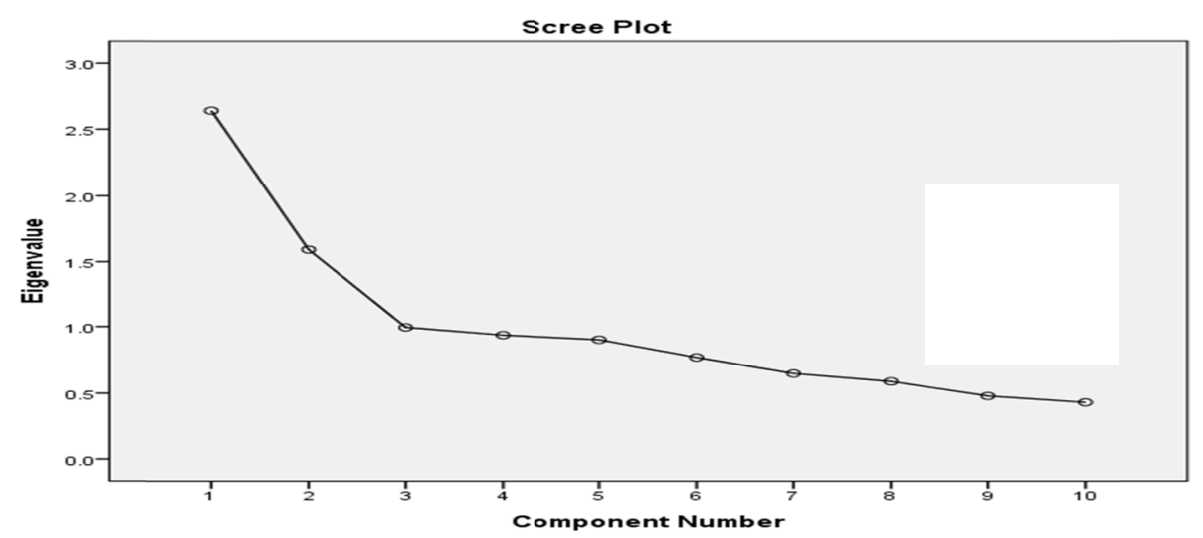

Figure 2. Scree plot for construction variables

Tables 10 and 11 show the outcome of the two factor solution. The two factor solution explained a total 42.21 percent of the variance and component 1 contributing 27.37 percent of the variance and component 2 contributing 14.84 percent for variables at design phase and the two factor solution explained a total 42.31 percent of the variance and component 1 contributing 23.09 percent of the variance and component 2 contributing 19.22 percent for variables at construction phase.

Table 10. Total variance explained by factors-design variable

\begin{tabular}{|c|c|c|c|c|c|c|c|c|c|}
\hline \multirow{2}{*}{ Component } & \multicolumn{3}{|c|}{ Initial Eigenvalues } & \multicolumn{3}{|c|}{ Extraction Sums of Squared Loadings } & \multicolumn{3}{|c|}{ Rotation Sums of Squared Loadings } \\
\hline & Total ${ }^{0}$ & 6 of Variance & Cumulative $\%$ & Total & $\%$ of Variance & Cumulative $\%$ & Total & $\%$ of Variance & Cumulative $\%$ \\
\hline 1 & 3.013 & 27.392 & 27.392 & 3.013 & 27.392 & 27.392 & 3.010 & 27.368 & 27.368 \\
\hline 2 & 1.630 & 14.820 & 42.212 & 1.630 & 14.820 & 42.212 & 1.633 & 14.844 & 42.212 \\
\hline 3 & 1.089 & 9.899 & 52.111 & & & & & & \\
\hline 4 & .970 & 8.822 & 60.933 & & & & & & \\
\hline 5 & .868 & 7.892 & 68.825 & & & & & & \\
\hline 6 & .762 & 6.925 & 75.749 & & & & & & \\
\hline 7 & .675 & 6.140 & 81.890 & & & & & & \\
\hline 8 & .567 & 5.156 & 87.046 & & & & & & \\
\hline 9 & .508 & 4.619 & 91.664 & & & & & & \\
\hline 10 & .500 & 4.549 & 96.214 & & & & & & \\
\hline 11 & .417 & 3.786 & 100.000 & & & & & & \\
\hline
\end{tabular}

Extraction Method: Principal Component Analysis. 
Table 11. Total variance explained by factors - construction variable

\begin{tabular}{|c|c|c|c|c|c|c|c|c|c|}
\hline \multirow{2}{*}{ Component } & \multicolumn{3}{|c|}{ Initial Eigenvalues } & \multicolumn{3}{|c|}{ Extraction Sums of Squared Loadings } & \multicolumn{3}{|c|}{ Rotation Sums of Squared Loadings } \\
\hline & Total $\mathrm{O}$ & of of Variance & Cumulative \% & Total & $\%$ of Variance & Cumulative $\%$ & Total & $\%$ of Variance & Cumulative $\%$ \\
\hline 1 & 2.642 & 26.419 & 26.419 & 2.642 & 26.419 & 26.419 & 2.309 & 23.090 & 23.090 \\
\hline 2 & 1.589 & 15.893 & 42.312 & 1.589 & 15.893 & 42.312 & 1.922 & 19.222 & 42.312 \\
\hline 3 & 1.000 & 10.001 & 52.313 & & & & & & \\
\hline 4 & .941 & 9.415 & 61.727 & & & & & & \\
\hline 5 & .906 & 9.065 & 70.792 & & & & & & \\
\hline 6 & .772 & 7.723 & 78.515 & & & & & & \\
\hline 7 & .650 & 6.501 & 85.016 & & & & & & \\
\hline 8 & .590 & 5.897 & 90.913 & & & & & & \\
\hline 9 & .479 & 4.787 & 95.700 & & & & & & \\
\hline 10 & .430 & 4.300 & 100.000 & & & & & & \\
\hline
\end{tabular}

Extraction Method: Principal Component Analysis.

For better interpretation of these two components, Varimax rotation was performed, suppressing loading less than 0.4 this cut-off point is appropriate for interpretative purposes (Steven, 2002 cited in Field, 2009). Varimax rotation solution is present in Table 12 and 13 revealed the existence of simple structure with components showing a number of strong loadings, and variable loading substantially on two components.

Table 12. Varimax rotation of two factor solution for design variables

\begin{tabular}{ccc}
\hline & \multicolumn{2}{c}{ Component } \\
\cline { 2 - 3 } & 1 & 2 \\
\hline Award tender to right Contractor & .665 & .662 \\
Sufficient Time & .660 & .402 \\
Involvement of relevant Professional & .613 & \\
Standardization of Procedure & .563 & .514 \\
Detailed of Design & .513 & .786 \\
Value Engineering & .510 & .741 \\
Initial Planning & .457 & \\
Project brief & & \\
Site Investigation & & \\
Contingency Sum & & \\
Award contact on fixed sum basis & & \\
\hline
\end{tabular}

Note. (i) Only loading above 0.4 are displayed;

(ii)Value Engineering is a complex variable(i.e., an item that is in a the situation of crossloading)

Table 13. Varimax rotation of two factor solution for construction variables

\begin{tabular}{ccc}
\hline & \multicolumn{2}{c}{ Component } \\
\cline { 2 - 3 } Continuous coodination & 1 & 2 \\
CO Procedure & .724 \\
Team Effort & .664 \\
Prompt approval procedure & .634 & .603 \\
Documentation of CO & .575 & .822 \\
Shared Database & .429 & .775 \\
Nominated Sub-Contractor & & .548 \\
Open tendering & & \\
Work Breakdown Structure & & \\
Independent Professional Mgr & &
\end{tabular}

Note. Only loading above 0.4 are displayed 
In order to establish the model of the relationship between management strategies and building outcome multiple regressions were performed using management at design stage and management at construction stage as independent variables with building outcome as the dependent variable. Prior to performing the multiple regression analysis a multicollinearity of independent and dependent variable was checked. Multicollinearity is the correlation between the variables in the model. According to Pallant (2001) a correlation relationship $>0.3$ and 0.7 is preferred.

Table 14. Correlations between independent and dependent variables

\begin{tabular}{ccccc}
\hline & & Building Outcome & Management at Design Management at Construction \\
\hline \multirow{4}{*}{ Pearson Correlation } & Building Outcome & 1.000 & .504 & .444 \\
& management at Design & .504 & 1.000 & .697 \\
& management at Construction & .444 & .697 & 1.000 \\
Sig. (1-tailed) & Building Outcome &. & .000 & .000 \\
& management at Design & .000 &. & .000 \\
& management at Construction & .000 & .000 & 323 \\
& Building Outcome & 323 & 323 & 323 \\
& management at Design & 323 & 323 & 323 \\
\hline
\end{tabular}

In Table 14 the correlation values of 0.504 and 0.444 were recorded for management at design and construction stage respectively. The result of these test show that all factors were appropriate for regression analysis.

The model Summary tells us whether the model is successful in predicting building project outcome (Table 15). Since the regression was hierarchical method; each set of summary statistics was repeated for each stage in the hierarchy. In the column regarded as $\mathrm{R}$ are the values of the multiple correlation coefficients between predictors and the outcome. The column characterized as $\mathrm{R}^{2}$ is a measure of how much of the changeability in the outcome is accounted for by the predictor. For the first model its value is .252 which means that change order management at the design stage accounts for $25.2 \%$ of the variation in building project outcomes. However when the other predictor (change order management at the construction stage) was included (Model 2) the value increased to .271 or $27.1 \%$ of the variation in building project outcome and it was not significant with $\mathrm{p}$-value $>.005$. This result suggests that it is not be appropriate to include all independent variable (management at construction stage) in the regression model.

Table 15. Model summary

\begin{tabular}{|c|c|c|c|c|c|c|c|c|}
\hline \multicolumn{9}{|c|}{ Model Summary $^{c}$} \\
\hline \multirow[b]{2}{*}{ Model } & \multirow[b]{2}{*}{$\mathrm{R}$} & \multirow{2}{*}{$\begin{array}{c}\mathrm{R} \\
\text { Square }\end{array}$} & \multirow{2}{*}{$\begin{array}{l}\text { Adjusted R } \\
\text { Square }\end{array}$} & \multirow{2}{*}{$\begin{array}{l}\text { Std. Error of the } \\
\text { Estimate }\end{array}$} & \multicolumn{3}{|c|}{ Change Statistics } & \multirow[b]{2}{*}{ Durbin-Watson } \\
\hline & & & & & $\begin{array}{l}\text { R Square } \\
\text { Change }\end{array}$ & $\underset{\text { Change }}{\text { F }}$ df1 df2 & $\begin{array}{c}\text { Sig. F } \\
\text { Change }\end{array}$ & \\
\hline 1 & $.504^{\mathrm{a}}$ & .254 & .252 & .633 & .254 & $109.402 \quad 1321$ & .000 & \\
\hline 2 & $.520^{\mathrm{b}}$ & .271 & .266 & .627 & .017 & 1320 & .007 & 1.749 \\
\hline
\end{tabular}

a. Predictors: (Constant), management at Design

b. Predictors: (Constant), management at Design, management at Construction

c. Dependent Variable: Building Outcome

The Anova table (Table 16) result tells us whether the model is significantly better at predicting the outcome. That is if enhancement due to fitting regression model is much larger than the imprecision within the model then the value of $\mathrm{F}$ will be greater than 1. For the first model F-ratio is 109.402 , which is very doubtful to have happened by chance $(\mathrm{p}<.001)$. The second model the value of $\mathrm{F}$ is less $(59.405)$, which is also highly significant $(p<.001)$. This result indicates that though the initial model has the ability to predict the outcome variable, but the addition of the extra predictor decreases it ability. This finding confirms the results in Table 15. 
Table 16. Model ANOVA

\begin{tabular}{ccccccc}
\hline & Model & Sum of Squares & df & Mean Square & F & Sig. \\
\hline \multirow{2}{*}{1} & Regression & 43.849 & 1 & 43.849 & 109.402 & $.000^{\mathrm{b}}$ \\
& Residual & 128.658 & 321 & .401 & & \\
& Total & 172.506 & 322 & & & \\
& Regression & 46.709 & 2 & 23.355 & 59.409 & $.000^{\mathrm{c}}$ \\
& Residual & 125.797 & 320 & .393 & & \\
\hline
\end{tabular}

a. Dependent Variable: Building Outcome

b. Predictors: (Constant), management at Design

c. Predictors: (Constant), management at Design, management at Construction

Table 17 shows the model parameters for both steps in the hierarchy. The first column of the table gives the estimates for b-values, which indicate the individual input of each predictor to the model. In this study the $\mathrm{b}$-values is positive meaning there is positive relationship between the predictors and outcome variable.

Table 17. Model parameter coefficients

\begin{tabular}{|c|c|c|c|c|c|c|c|c|}
\hline & \multirow[t]{2}{*}{ Model } & \multicolumn{2}{|c|}{$\begin{array}{c}\text { Unstandardized } \\
\text { Coefficients }\end{array}$} & \multirow{2}{*}{$\begin{array}{c}\begin{array}{c}\text { Standardized } \\
\text { Coefficients }\end{array} \\
\text { Beta }\end{array}$} & \multirow[t]{2}{*}{$\mathrm{t}$} & \multirow[t]{2}{*}{ Sig. } & \multicolumn{2}{|c|}{ Collinearity Statistics } \\
\hline & & $\mathrm{B}$ & Std. Error & & & & Tolerance & VIF \\
\hline \multirow{3}{*}{1} & (Constant) & 1.126 & .290 & & 3.883 & .000 & & \\
\hline & management at Design & .771 & .074 & .504 & 10.460 & .000 & 1.000 & 1.000 \\
\hline & (Constant) & .967 & .293 & & 3.300 & .001 & & \\
\hline \multirow[t]{2}{*}{2} & management at Design & .580 & .102 & .379 & 5.699 & .000 & .515 & 1.942 \\
\hline & management at Construction & .250 & .093 & .179 & 2.698 & .007 & .515 & 1.942 \\
\hline
\end{tabular}

a. Dependent Variable: Building Outcome

It can also be seen in the second model that $\mathrm{p}$ value of $.007>.005$ making it not significant. This finding indicates that change order management at the construction stage should not be included as a predictor variable in the regression model.

The basic equation of multiple regressions is:

$$
\text { Outcome }_{\mathrm{i}}=(\text { model })+\text { error }_{\mathrm{i}}
$$

It is essentially the same for simple regression except that for every additional predictor included. In this study two predictor variables are used therefore the will be:

Where:

$$
\mathrm{Y}_{\mathrm{i}}=\mathrm{b}_{0}+\mathrm{b}_{1}\left(\mathrm{X}_{\mathrm{i} 1}\right)+\mathrm{b}_{2}\left(\mathrm{X}_{\mathrm{i} 2}\right)+\varepsilon_{\mathrm{i}}
$$

$\mathrm{Y}_{\mathrm{i}}=$ the outcome variable

$\mathrm{b}_{0}=$ the intercept (constant)

$\mathrm{b}_{1} ; \mathrm{b}_{2}$ individual contribution of each predictor to the model

$\mathrm{X}_{\mathrm{i} 1}=$ management strategies at design stage

$\mathrm{X}_{\mathrm{i} 2}=$ management strategies at construction stage

It is important to note that since the second predictor in this study is not significant the equation becomes:

$$
\mathrm{Y}_{\mathrm{i}}=\mathrm{b}_{0}+\mathrm{b}_{1}\left(\mathrm{X}_{\mathrm{i} 1}\right)+\varepsilon_{\mathrm{i}}
$$

Replacing the variable value as given in Table 17:

$$
\text { Outcome }=1.13+0.77\left(\mathrm{X}_{\mathrm{i} 1}\right)+\varepsilon_{\mathrm{i}}
$$

This finding indicate that as change order management effort increases by one (1) unit, building outcome 
increases by 0.77 units.

The final step was assessing the accuracy of a model across different samples; known as cross validation. If a model can be generalized, then the model must be capable of precisely predicting the same outcome from the same sets of predictor in a different group of respondents. Cross validation of this model was achieved using Stein's equation (Stevens, 2002 cited in Field, 2009). Stein equation is given by:

Where

$$
\text { Adjusted } R^{2}=1-\left[\left(\frac{n-1}{n-k-1}\right)\left(\frac{n-2}{n-k-2}\right)\left(\frac{n+1}{n}\right)\right]\left(1-R^{2}\right)
$$

$\mathrm{n}=$ sample size;

$\mathrm{K}=$ number of predictors

By replacing $\mathrm{n}$ with the sample size (323) and $\mathrm{k}$ with the number of predictors (2)

$$
\text { Adjusted } R^{2}=1-\left[\left(\frac{323-1}{323-1-1}\right)\left(\frac{323-2}{323-2-2}\right)\left(\frac{323+1}{323}\right)\right](1-0.252)
$$

Adjusted $\mathrm{R}^{2}=1-(1.0)(1.01)(1.00) 0.748$

$$
\begin{aligned}
& =1-0.755 \\
& =0.245
\end{aligned}
$$

This value is very comparable to the observed value $\mathrm{R}^{2}(0.252)$. This finding indicates that the cross -validity of the model is very good and thus can be used to generalise.

\section{Discussion}

Clear and thorough project brief is the first most important change order management strategy for building projects in northern Nigeria. The findings seems to suggest that project briefing by Nigeria clients are inadequate and that project teams allow clients to leave their briefing decision unresolved until the very late stages of projects. Clear and thorough project brief helps in clarifying the project objective to all project participants. This minimizes design error and non-compliance with the owner's requirements. Better initial planning came second among the three top-most important change order management strategies in building projects in northern Nigeria. This finding implies that project planning is not properly carried out in the Nigeria construction industry, and this could be a pointer to the fact that most errors found in contract documents result from inadequate planning. The finding also supports findings that project implementation is not correctly executed in most building projects in Nigeria.

Thorough detailing of drawing design was ranked the third most important change order management strategy in building projects in northern Nigeria where most contracts are based on drawings and specification. A well-detailed design is readily understood by construction professionals. This assists in identifying the errors, omissions and ambiguities in design at an early stage and helps avoid claims and disputes. This finding suggests that clients should allow sufficient time for designers to design, and also develop contract documents. This finding supports other researches, that building project in Nigeria are often hurriedly started without proper planning and as a result design consultants are put under pressure to deliver design drawings in order to meet up with deliver dates and in most led to lapses in design detailing. A possible explanation for this finding is that changes during design phase do not require any rework or demolition because no site work is involved.

The multiple regression model has established the relationship between outcome and change order management strategies. The model in this study has provided empirical support that management strategies at design stage contribute most to the control of change order in building projects in northern Nigeria.

\section{Conclusion}

This paper was conducted to identify management strategies for building project and their relative importance and (ii) to determine the relationship between change order management strategies and building project success, by examining the perception of 323 respondents with different work experience and background in the Nigerian construction industry.

The findings show consensus of opinion among the respondents on change order management strategies.

Furthermore, the study found that change order management is $25.2 \%$ correlated with project success, but also shows quite clearly that $74.8 \%$ of project success cannot be explained by change order management. Based on the finding of this study the following recommendation are envisaged to help minimize change orders in project 
delivery in Northern Nigeria

(i) Project sponsor need to properly adopt and use project implementation phase principles

(ii) Increased effort at the design stages of projects.

(iii) Allocation of adequate resources to project requirement

(iv) Adhere to budgeting provisions

\section{References}

Ade-ojo, C., \& Babalola, A. (2013). Cost and Time Performance of Construction Projects under Due Process Reform in Nigeria. International Journal of Engineering and Science, 3(6), 1-6. Retrieved from http://www.researchinventy.com/papers/v3i6/A0360106.pdf

Aibinu, A., \& Jagboro, G. (2002). The Effect of Construction Delay on Project Delivery in Nigerian Construction Industry. International Journal of Project Management, 20, 593-599. http://dx.doi.org/10. 1016/S0263-7863(02)00028-5

Al-tmeemy, S. M., Abdul - Rahman, H., \& Harun, Z. (2011). Future criteria for success of building projects in Malaysia. International Journal of Project Management, 29(3), 337-348. http://dx.doi.org/10.1016/j. ijproman.2010.03.003

Ameh, J., \& Odusami, K. (2010). Nigerian Building Professionals' Ethical Ideology and Perceived Ethical Judgement. Australian Journal of Construction Economics and Building 10(3), 1-13. http://dx.doi.org/10.5130/AJCEB.v10i3.1602

Arain, F., \& Pheng, L. (2006). Effective Management of Contract Variations using Knowledge Based Decision Support Systems. Cadiff: Centre for Education in the Built Environment.

Arain, F., \& Pheng, L. (2007). Modelling for Management of Variation in Building Projects. Engineering Construction and Architectural Management 14(5), 420-433. http://dx.doi.org/10.1108/09699980710 780737

Atkinson, R. (1999). Project Management:Cost time and quality, two best guesses and a phenomenon, its time to accept other criteria. International Journal of Project Management, 17(6), 337-342. http://dx.doi.org/10.1016/S0263- 7863(98)00069-6

Chan, A. P. (2000). Evaluation of enhanced design and building system: A case study of a hospital project. Construction Management and Economics, 18(8), 863-871. http://dx.doi.org/10.1080/014461900433140

Charoenngam, C., Coquinco, S. T., \& Hadikusumo, B. W. (2003). Web-based application for managing change orders in construction projects. Journal of Construction Innovation, 197-215. http://www.emeraldinsight. $\mathrm{com} / . . / 1471417031081$

Dahiru, A., \& Mohammed, I. (2012). The Roles of Researchers in the Construction Sector towards Achieving Millenium Development Goals. Journal of Science \& Multidisciplinary Research, 4, 80-93. Retrieved from http://www.cenresinpub.org/pub/The\%20Roles\%20of\%20Researchers\%20in\%20the\%20Construction.pdf

Erdogan, B., Anumba, C., Bouchlaghem, D., \& Nielsen, Y. (2005). Change Management in Construction: The Current Context. 21st Annual ARCOM Conference (pp. 1085-1095). London: ARCOM. Retrieved from http://www.researchgate.net/profile/Chimay_Anumba/publication/265999946

Field, A. (2009). Discovering Statistics Using SPSS 3rd Edition. London: SAGE Publications Limited. Retrieved from http://senas.lnb.lt/stotisFiles/uploadedAttachments/9_Discovering_statistics_using_SPSS2010125104 26.pdf

Frodell, M. (2008). Swedish construction clients' views on project success and measuring performance. Journal of Engineering Design and Technology, 6, 21-32. http://dx.doi.org/10.1108/17260530810863316

Ibbs, C., Womg, C., \& Kwak, Y. (2001). Project Change Management System. Journal of Management in Engineering ASCE, 17(3), 159-165. Retrieved from http://home.gwu.edu/ kwak/PCMS.pdf

Kylindri, S., Blanas, G., Henriken, L., \& Stoyan, T. (2012). Measuring Project Outcomes: A Review of Success Effectiveness Variables. Oral -MIBES (pp. 212-223). Retrieved from November 29, 2015, http://mibes. teilar.gr/proceedings/2012/oral/Kylindri-Blana-Henriksen-Tanev.pdf

Lim, C. S., \& Mohammed, M. Z. (1999). Criteria of Project Success: an exploratory re-examination. International Journal of Project Management, 17(4), 243-248. http://dx.doi.org/10.1016/S0263-7863(98)00 
$040-4$

Mokhtar, A., Bedard, C., \& Fazio, P. (2000). Collaborative planning and schedulling of interrelated design changes. Journal of Architectural Engineering ASCE, 6(2), 66-75. http://dx.doi.org/10.1061/(ASCE)10760431(2000)6:2(66)

Motowa, I. (2005). Asystematic Approach to Modelling a Change Process in Construction Projects. Journal of Construction Economics and Building, 5(1), 23 -31. http://dx.doi.org/10.5130/AJCEB.v5i1.2940

Motowa, I. A., Anumba, C. J., Lee, S., \& Pena-Mora, F. (2007). An Intergrated system for change management in construction. Journal of Automation in Construction, 368-377. http://dx.doi.org/10.1016/j.autcon.2006. 07.005

Ogwueleka, A. (2011). The Critical Success Factors Influencing Project Performance in Nigeria. International Journal of Management Science and Engineering Management, 6(5), 343-349. http://dx.doi.org/10.1080/ 17509653.2011.10671182

Oladapo, A. (2007). A Quantitative Assessment of the Cost and Time Impact of Variation Orders on Construction Projects. Journal of Engineering, Design and Technology, 5(1), 35-48. http://dx.doi.org/10.1108/1726 0530710746597

Oloo, D., Munala, G., \& Githae, W. (2014). Factors Contributing to Variation Orders: A survey of Civil Engineering Construction Projects in Kenya. International Journal of Social Science and Entrepreneurship, 1(12), 696-709. Retrieved from http://www.ijsse.org/articles/ijsse_v1_i12_696_709.pdf

Pallant, J. (2007). SPSS Survival Manual: A Step by Step to Data Analysis Using SPSS Third Ed. Allen \& Unwin, Australia. Retrieved November 30, 2015, from http://www.academia.dk/BiologiskAntropologi/Epidem iologi/PDF/SPSS_Survival_Manual_Ver12.pdf

Pinto, M. B., \& Pinto, J. K. (1991). Determinants of cross-functional cooperation in project implementation process. Project Management Journal, 22, 13-20.

Pocock, J. B., Hyun, C. T., Lim, L. Y., \& Kim, M. K. (1996). Relationship between project interaction and performance indicators. Journal of Construction Engineering and Management, 165-176. http://dx.doi.org/10.1061/(ASCE)0733- 9364(1996)122:2(165)

Pourrostam, T., \& Ismail, A. ( 2011) . Significant factors Causing and Effect of delay in Iranian Construction Projects. Australian Journal of Basic Applied Science, 5(7), 450-456. Retrieved from http://www.ijetch.org/ papers/441-P10022.pdf

Sun, M., Senattena, S., Fleming, A., Motowa, I., \& Yeoh, M. (2006). A change menagement toolkit for construction projects. Architectural Engineering and Design Management 2(4), 261-271. http://dx.doi.org/10.1080/17452007.2006.9684621

Sunday, O. (September 6-8, 2010). Impact of Variation Order on Public Construction Projects. In Egbu C(Ed) Proceedings 26th Annual ARCOM Conference (pp. 101-110). Leeds United Kingdom: Association Researchers in Construction Management. Retrieved from http:/www.arcom.ac.uk/-docs/proceedings/ ar2010-0101-0110_Sunday.pdf.Retrived4/12/2015

Ubani, E., Nwachukwu, C., \& Nwokonkwo, O. (2010). Variation Factors of Project Plan and Their Contribution to Project Failure in Nigeria. American Journal of Social and Management Science, 1(2), 141-149. Retrieved from http://scihub.org/AJSMS/PDF/2010/2/AJSMS-1-2-141-149.pdf

Usman, N. D., Inuwa, I. I., Iro, I. A., \& Dantong, S. (2012). The Influence of unethical professional Practices on the management of Construction Projects in North-Eastern States of Nigeria. International Journal of Economic Development Research and Invesrtment, 3(2), 1-12. Retrieved from http://ssrn.com/abstract= 2250604

\section{Copyrights}

Copyright for this article is retained by the author(s), with first publication rights granted to the journal.

This is an open-access article distributed under the terms and conditions of the Creative Commons Attribution license (http://creativecommons.org/licenses/by/3.0/). 